
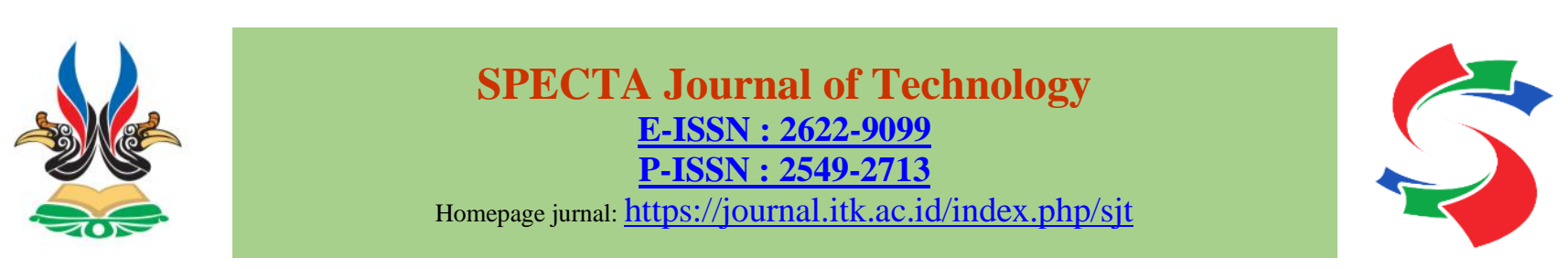

\title{
Implementation of Telemarketing Inbound Call in Mass Market Segment Division Telkomsel Semarang Branch
}

\author{
Anissa Septyorini ${ }^{1}$, Robetmi Jumpakita Pinem ${ }^{2 *}$ \\ ${ }^{1}$ Department of Marketing Management, Vocational School, Diponegoro University \\ ${ }^{2}$ Department of Business Administration, Faculty of Social and Political Science, Diponegoro University \\ *Email: robetmi@lecturer.undip.ac.id
}

\begin{abstract}
The development of technology and the communication world is growing rapidly so that telecommunications companies are competing to take a role in it. Technology and communication facilities play an important role in human life today. One of the company's objectives is customer loyalty to its products to keep it awake. To maintain the loyalty of Telkomsel customers implement several promotional strategies that one of them is telemarketing. The purpose of this research is to know how to apply to telemarket used by Telkomsel Branch Semarang. Based on research and theory reviews, telemarketing is divided into two of the inbound telemarketing and outbound telemarketing. Telkomsel Branch Semarang's marketing team uses outbound telemarketing to increase customer product understanding, optimize usage of Telkomsel providers, and meet sales targets. This method of research is a qualitative descriptive method, which aims to describe and describe the characteristics of the phenomenon. Data collection techniques in the form of interviews, observations, library studies, and Internet media. Based on the results and discussion of the author's review, the telemarketing used proved successful. Out Bound Calls results based on this study indicate that the telemarketing strategy used is quite effective because when viewed from the results there is an increase in the use of $4 \mathrm{G}$ networks.
\end{abstract}

Keywords: telemarketing, outbound call, implementation

\begin{abstract}
Abstrak
Perkembangan dunia teknologi dan komunikasi semakin pesat sehingga perusahaan telekomunikasi berlombalomba untuk mengambil peran di dalamnya. Fasilitas teknologi dan komunikasi memegang peranan penting dalam kehidupan manusia saat ini. Salah satu tujuan perusahaan adalah loyalitas pelanggan terhadap produknya agar tetap terjaga. Untuk menjaga loyalitas pelanggan, Telkomsel menerapkan beberapa strategi promosi yang salah satunya adalah telemarketing. Tujuan dari penelitian ini adalah untuk mengetahui bagaimana penerapan telemarket yang digunakan oleh Telkomsel Cabang Semarang. Berdasarkan kajian penelitian dan teori, telemarketing dibedakan menjadi dua yaitu inbound telemarketing dan outbound telemarketing. Tim pemasaran Telkomsel Cabang Semarang menggunakan outbound telemarketing untuk meningkatkan pemahaman produk pelanggan, mengoptimalkan penggunaan provider Telkomsel, dan memenuhi target penjualan. Metode penelitian ini adalah metode deskriptif kualitatif yang bertujuan untuk mendeskripsikan ciri-ciri fenomena. Teknik pengumpulan data berupa wawancara, observasi, studi pustaka, dan media internet. Berdasarkan hasil dan pembahasan review penulis, telemarketing yang digunakan terbukti berhasil. Hasil Out Bound Calls berdasarkan penelitian ini menunjukkan bahwa strategi telemarketing yang digunakan cukup efektif karena jika dilihat dari hasil terdapat peningkatan penggunaan jaringan $4 G$.
\end{abstract}

Kata Kunci: telemarketing, outbound call, implementasi 


\section{Introduction}

Due to the new era of increasing technology demands, electronic products are growing rapidly (Yen, 2019) so that companies are competing to take a role in it. Technology and communication facilities play an important role in human life today. Through communication technology, humans can exchange information from a distance with a relatively fast and efficient time. In the past, many people only used home telephones to communicate, but now they can communicate without having to use cables and are easy to carry anywhere. Telecommunications is very important because telecommunications networks can transfer information between regions in an instant. The rapid development of technology and being aware of the importance of getting information makes people interested in using the internet to access various information or carry out communication activities using the internet.

The development and smoothness of communication facilities are increasingly demanded to increase quality in order to expedite existing communication facilities so that adequate human resources are required and have the latest expertise and innovation to apply their knowledge. Competition in providing telecommunications services to provide products needed by the community so that the product can be accepted by the market. Strategy planning forms the basis of how the company moves against competitors and enters the market. A good plan can be the basis and clarify the steps that the company will take to retain its customers. Telkomsel Semarang Branch wants to maintain customer loyalty by providing the best service for customers.

Table 1: The number of Telkomsel 3G network users in the Semarang Branch area in April 2020

\begin{tabular}{cc}
\hline City/ District & Users \\
\hline Demak & 74.909 \\
Jepara & 112.304 \\
\hline Kendal & 55.025 \\
\hline Kota Salatiga & 16.509 \\
\hline Kota Semarang & 196.595 \\
\hline Kudus & 68.598 \\
\hline Pati & 146.344 \\
\hline Rembang & 56.463 \\
\hline Semarang & 63.906 \\
\hline Total & 790.653 \\
\hline
\end{tabular}

Source: Telkomsel Semarang Branch

High $3 \mathrm{G}$ users will the smooth network in the exchange of information and the Internet. This will disturb the customer and include unsatisfactory service. Therefore, Telkomsel Semarang Branch optimizes the SIM card that customers use, from the $3 \mathrm{G}$ network to the $4 \mathrm{G}$ network. Carrying out its objectives, the Semarang Branch Telkomsel arranged plans using Outbound Call Telemarketing.

Telemarketing is the use of telephones to sell products directly to consumers and business customers (Kotler and Armstrong, 2012). Kotler and Keller (2012) Telemarketing is the use of telephone and call centers to attract prospects, sell products to customers, and provide services to customers. It can be concluded that Telemarketing is the use of telephone and data centers to sell products directly and provide services to customers with the aim of making a profit. The use of communication technology through telemarketing as one of the dominant forms of direct marketing is expected to provide 
convenience for customers to access information needed in the stages of the Purchasing Decision Process.

According to Kotler and Keller (2012) Telemarketing is divided into two types:

a. Inbound Telemarketing

Inbound telemarketing is the use of toll-free telephone numbers to receive orders from advertisements, direct mail, or catalogs (Kotler and Armstrong, 2012). Kotler and Keller (2012) Inbound telemarketing is incoming telephone calls originating from customers. It can be concluded that Inbound Telemarketing is an incoming telephone call from a customer with the intention of wanting to order a product, or just asking about a product, even asking for problems encountered in the product purchase decision process. Examples of Inbound Telemarketing are customers who want to order a product that has been promoted by the company, then the customer calls and asks about the product being promoted.

b. Outbound Telemarketing

Outbound telemarketing is using an outgoing telephone to sell products directly to customers (Kotler and Armstrong, 2012). Brendremer (2003) Outbound telemarketing is an outgoing telephone call, with the aim of selling products, making appointments with customers, and promoting products. It can be concluded that Outbound Telemarketing is an outgoing telephone call aimed at customers with the aim of selling products, making appointments and promoting products directly. An example of Outbound Telemarketing is Telemarketing that calls customers to promote the company's new products to customers.

According to Nurdin Usman in his book entitled Curriculum-Based Implementation Context (2002) expresses his opinion regarding the implementation or implementation boils down to activities, actions, actions, or the existence of a system mechanism. Implementation is not just an activity, but a planned activity and to achieve the objectives of the activity. The definition of implementation stated above, it can be said that implementation is not just an activity, but an activity that is planned and carried out seriously based on a reference to certain norms to achieve the objectives of the activity. Therefore, the implementation does not stand alone but is influenced by the next object.

According to Guntur Setiawan in his book entitled Implementation in the Development Bureaucracy (2004: 39) expresses his opinion regarding implementation or implementation as an expansion of activities that mutually adjust the process of interaction between goals and actions to achieve them and require an effective network of implementers, bureaucracy. The definition of implementation stated above, it can be said that implementation is a process for implementing a new idea, process or set of activities in the hope that other people can accept and make adjustments in the bureaucracy in order to create a goal that can be achieved with a trustworthy implementing network. According to Hanifah Harsono in his book entitled Implementation of Policy and Politics, expresses his opinion on the implementation or implementation of a process to implement policy into policy action from politics to administration. Policy development in order to improve a program.

\section{Methods}

The research method used is a qualitative method. Qualitative research method is a descriptive research method, uses analysis, refers to data, utilizes theory. The research location for this final project is Telkomsel Semarang Branch. This type of research is a descriptive study that aims to describe what is currently happening. With descriptive research described in detail about all marketing activities that have been obtained to the reader so as to obtain a clear picture of the Implementation of Telemarketing Out Bound Call at Telkomsel Branch Semarang. Analysis of data using qualitative descriptive methods ie data obtained in the study reported as is then analyzed descriptively to get a picture of the facts that occur. 


\section{Result and Discussion}

Telemarketing must be managed according to the principle of sustainability. to avoid a sudden and almost permanent drop decreased consumer response (Hurst. C.G. 2008.). The number of Telkomsel users in the Semarang Branch in April 2020. The use of $3 \mathrm{G}$ networks is still quite high because the numbers still reach tens of thousands or even hundreds of thousands. From this data, the company devised a strategy so that the numbers on the $3 \mathrm{G}$ network fell and the numbers on the $4 \mathrm{G}$ network increased. Outbound Call Telemarketing planning with $5 \mathrm{~W}+1 \mathrm{H}$ is arranged, namely:

1. What: What goals do you want to achieve? "Optimizing the use of the $4 \mathrm{G}$ network, such as replacing all numbers that are still $3 \mathrm{G}$ networks to the $4 \mathrm{G}$ network and giving offers to customers whose networks are already $4 \mathrm{G}$ but have never been used"

2. Why: Why is that a goal? Because in meeting customer needs in terms of telephone speed, sending messages, and the internet on Telkomsel's network. Seta ensures that what the consumer gets is in accordance with the budget they spend, in line with what the company expects.

3. Where: Where is the most appropriate location to reach the destination? In the Semarang Branch area (Telkomsel Semarang Branch administrative area).

4. When: When must the work be completed in order to achieve the goal (related to the schedule)? Data entered on the Out Bound Call website is monthly data. For each month, 2000 targeted numbers are dialed, and for each day are 100 numbers.

5. Who: Who are the right people to be chosen to carry out the work in connection with the objectives? Telkomsel Semarang Branch will appoint some of its employees to become telemarketing staff and apprentices there to help.

6. How: What are the methods or ways of carrying out work in an effort to achieve goals? So that all goes well and smoothly, before carrying out telemarketing telemarketing officers are trained in advance to handle customers with a variety of characteristics.

Following are the stages of planning made by Telkomsel Semarang Branch:

First the objectives of telemarketing activities will be determined. The purpose of telemarketing from Telkomsel Semarang branch is twofold, the first is to inform customers and confirm that the Sim card used by the customer is that the network used is still $3 \mathrm{G}$, the customer will be offered to change the network to $4 \mathrm{~g}$ with the choice of the customer coming alone to Grapari or sales from Telkomsel who will come to meet with customers at the agreed time and place. The second is a notification to customers with selected numbers that the numbers are entitled to get attractive promos from Telkomsel in the form of OMG internet quota. OMG quota is one of Telkomsel's products in the form of a full 24-hour quota.

Second, make a script that will be used for telemarketing activities. This is quite important, because some people will be confused if they do not arrange words first before talking to customers on the phone. The manuscript is made by the Semarang Branch Telkomsel marketing team which will then be given to the telemarketing officer. The manuscript not only contains the words used to talk to the customer, but also contains the flow from the beginning of the call to the final action agreed upon. Manuscripts containing the words commonly used are usually "Good Morning / Afternoon, Father or Mother, introduce me Bintang from Telkomsel Branch Semarang. Previously I apologize for disturbing the time. So I want to confirm whether the number you use is actually $3 \mathrm{G}$ networked, if yes we have an offer if you exchange a $3 \mathrm{G}$ card with a $4 \mathrm{G}$ card then you will get a large $10 \mathrm{~Gb}$ quota and how to exchange cards can come to Grapari or if you are busy our team can send the card to your house. Thanks for the time bag. Good Morning/ Afternoon ".

Third is to prepare telemarketing personnel who will carry out their duties. They must be prepared and practice how to speak well with the rules that have been determined. The rules include, speaking in a professional voice (Smiling voice) or Smiling voice means a smiling voice, meaning speaking in a voice that makes people who hear can imagine that the speaker is smiling. Smiling voice can make people who listen feel the speaker is smiling without face to face. So before doing OBC, OBC staff will be given time to study with a script and with smiling voice about 2 days later they will only do $\mathrm{OBC}$ activities. 
Fourth, prepare the media for telemarketing such as cellphones that are fully charged and the cellphones are already filled with telephone packages. After making a careful plan, the plan will be implemented. $\mathrm{OBC}$ activities carried out per day are at least 100 numbers per City or Regency. The first thing to do is to provide media to conduct telemarketing activities in the form of mobile phones that have been filled with telephone packages. Then the OBC officer will $\log$ in on a special website created by Telkomsel itself for OBC activities.

The website was created by Telkomsel specifically for OBC activities, the contents of the website are customer numbers, customer clusters (City / Regency), the value of the customer's SIM card (level of use), and actions to be agreed upon by customers and telemarketing officers. There are two Outbound Calls (OBC) of Telkomsel Semarang Branch, OBC OTA and OBC OMG. OBC OTA is an outgoing call made by a company to provide information and offers to customers about the SIM card that customers use. The focus of OBC OTA is migration from $3 \mathrm{G}$ networks to $4 \mathrm{G}$ networks, Telkomsel provides an option if the customer wants to change the network to $4 \mathrm{G}$ then the customer will get a reward from Telkomsel in the form of a 10GB quota by offering customers to exchange SIM cards directly to the nearest Telkomsel Grapari or customers can choose delivery (Sales from Telkomsel will send a SIM card to the address and time agreed upon with the customer).

Whereas OBC OMG is an outgoing call made by the company with the aim of providing information about quota promo offers that customers get (each number differs according to the value the customer has, the value has been set by Telkomsel). The quota promo has 4 values, the more the cheaper the price. Value 1 (4Gb, active period of 7 days) with a price of Rp. 10,000, value 2 (4Gb, 7 Days) at a price of Rp. 1000, value 3 (4Gb, 7 Days, 100 minutes telephone, $200 \mathrm{Sms}$ ) Rp. 1000, and the last value 4 (4Gb 7 Days) Rp. 10. In OBC OMG the customer has two choices, the first is accepting the offer or rejecting the offer for a clear reason and then the reason will be written by the OBC officer on the website. The reason that is often encountered is usually because the mobile phone that the customer uses is $3 \mathrm{G}$, or the $4 \mathrm{G}$ signal in his area is still difficult to access.

Nancarrow and Sally (1998) checked that there is a special need to be understood by telemarketers how relationships can be developed over the telephone. Basically, Telkomsel Branch Semarang focuses the activities of Outbound Call (OBC) results so that $4 \mathrm{G}$ network usage can increase and optimize. Because this is done to improve the quality of its consumers, because the internet does have a very big appeal, where people can open their horizons as widely as possible by simply accessing the internet anywhere and anytime.

Table 2: Telkomsel User Data at Semarang Branch in April 2020

\begin{tabular}{|c|c|c|}
\hline \multirow[t]{2}{*}{ District/ City } & \multicolumn{2}{|c|}{ Users } \\
\hline & 3G & 4G \\
\hline Demak & 74.909 & 82.747 \\
\hline Jepara & 112.304 & 108.077 \\
\hline Kendal & 55.025 & 71.440 \\
\hline Kota Salatiga & 16.509 & 23.297 \\
\hline Kota Semarang & 196.595 & 269.128 \\
\hline Kudus & 68.598 & 76.267 \\
\hline Pati & 146.344 & 162.941 \\
\hline Rembang & 56.463 & 50.004 \\
\hline Semarang & 63.906 & 89.303 \\
\hline Total & 790.653 & 933.204 \\
\hline
\end{tabular}

Source: Mass Market Segment Team Semarang Branch

The Table 2 shows the number of Telkomsel users at the Branch Semarang in April 2020. It shows that the use of $3 \mathrm{G}$ networks is still quite high because the numbers still reach tens of thousands or even hundreds of thousands. This is offset by the $4 \mathrm{G}$ users shown in the table reaching tens of thousands or 
even hundreds of thousands. Most of all districts / cities in Central Java experienced an increase in the number of $4 \mathrm{G}$ users as a result of telemarketing activities. This shows that telemarketing activities carried out by Telkomsel Semarang Branch are successful in carrying out their programs. Several districts / cities still have higher $3 \mathrm{G}$ users than $4 \mathrm{G}$ and it is hoped that this program can increase the number of $4 \mathrm{G}$ users in Central Java province.

Table 3: Telkomsel User Data at Semarang Branch in May 2020

\begin{tabular}{|c|c|c|}
\hline \multirow[t]{2}{*}{ District/ City } & \multicolumn{2}{|c|}{ Users } \\
\hline & 3G & 4G \\
\hline Demak & 74.167 & 83.583 \\
\hline Jepara & 111.192 & 108.620 \\
\hline Kendal & 54.480 & 79.377 \\
\hline Salatiga & 16.346 & 29.121 \\
\hline Semarang & 194.649 & 336.410 \\
\hline Kudus & 67.917 & 95.333 \\
\hline Pati & 144.895 & 181.045 \\
\hline Rembang & 55.904 & 54.504 \\
\hline Semarang & 63.272 & 99.226 \\
\hline Total & 782.822 & 1.067 .219 \\
\hline
\end{tabular}

Source: Mass Market Segment Team Semarang Branch

In the Table 3, in May the numbers on $3 \mathrm{G}$ networks are still still there it shows tens of thousands, even hundreds of thousands, but when compared to that, the numbers tend to decrease compared to the April table. Meanwhile, the $4 \mathrm{G}$ network has increased.

Table 4: Presentation of increase / decrease in 3G networks from April to May

\begin{tabular}{clc}
\hline No & District/City & $\begin{array}{c}\text { Percentage Increase / Decrease } \\
\text { 3G network }(\%)\end{array}$ \\
\hline 1 & Demak & $-0,01$ \\
\hline 2 & Jepara & $-0,01$ \\
\hline 3 & Kendal & $-0,01$ \\
\hline 4 & Kota Salatiga & $-0,01$ \\
\hline 5 & Kota Semarang & $-0,01$ \\
\hline 6 & Kudus & $-0,01$ \\
\hline 7 & Pati & $-0,01$ \\
\hline 8 & Rembang & $-0,01$ \\
\hline 9 & Semarang & $-0,01$ \\
\hline & Source: Mass Market Segment Team Semarang Branch
\end{tabular}

The Table 4 shows that the $3 \mathrm{G}$ network in the Semarang Branch area has decreased by $0.01 \%$ in each City / Regency. Some of the reasons that make users still use $3 \mathrm{G}$ are usually because the cellphone that the customer uses is still $3 \mathrm{G}$ and the $4 \mathrm{G}$ network in the area is less stable, even the distance between home and Telkomsel's Grapari is far away. Therefore, Telkomsel provides a solution to this by expanding the $4 \mathrm{G}$ network to remote areas, and providing $4 \mathrm{G}$ card delivery services to customers' homes. 
Table 5: Presentation of increase / decrease in 4G networks from April to May Presentasi Kenaikan/Penurunan

No Kota/Kabupaten

\begin{tabular}{llc} 
No & Kota/Kabupaten & Jaringan $4 \mathrm{G}(\%)$ \\
\hline 1 & Demak & 0,01 \\
\hline 2 & Jepara & 0,01 \\
\hline 3 & Kendal & 0,11 \\
\hline 4 & Kota Salatiga & 0,25 \\
\hline 5 & Kota Semarang & 0,25 \\
\hline 6 & Kudus & 0,25 \\
\hline 7 & Pati & 0,11 \\
\hline 8 & Rembang & 0,09 \\
\hline 9 & Semarang & 0,11 \\
\hline & Source: Mass Market Segment Team Semarang Branch
\end{tabular}

Based on the Table 5, there was an increase in $4 \mathrm{G}$ network users from April to May. This increase could have been influenced by OBC activities used by Telkomsel Branch Semarang and new users who have just registered their $4 \mathrm{G}$ Telkomsel SIM card. Increased $4 \mathrm{G}$ network usage, and decreased $3 \mathrm{G}$ usage from April to May. This shows that the OBC carried out by Telkomsel Branch Semarang is quite effective for its purpose, namely optimizing $4 \mathrm{G}$ usage with evidence of an increase in users from April to May, and a decrease in $3 G$ network usage from April to May. Geetika, et. al. (2012) Telemarketing has emerged as an important tool of marketing; however, the companies should be very careful while calling using telemarketing.

\section{Conclusion}

Based on the results of research and data collection conducted at Telkomsel Semarang Branch, the conclusion is obtained regarding the Telemarketing Out Bound Call activities of the Telkomsel Semarang Branch. Telemarketing activities used by Telkomsel Semarang Branch use the concept of Out Bound Calls or outgoing calls to customers with the aim of offering goods or services, and providing information. The OBC planning made by Telkomsel Semarang Branch is good enough, so that the OBC activities run smoothly. The implementation of $\mathrm{OBC}$ in Telkomsel Semarang Branch is twofold, namely OBC OTA and OBC OMG, both goals are almost the same, namely optimizing the use of $4 \mathrm{~g}$ networks in the Semarang branch area. OBC results based on this study indicate that the telemarketing strategy used is quite effective because when viewed from the results there is an increase in the use of $4 \mathrm{G}$ networks from April to May 2020.

\section{Suggestion}

Based on the results of the discussion previously described, the suggestions given to the Telkomsel Branch Semarang to further improve telemarketing quality include in this Telemarketing activity Telkomsel Branch Semarang uses the concept of Out Bound Call, it should be balanced by using the concept of In Bound Call as well. In the planning concept of OBC Telkomsel Branch Semarang, it should always be changed in line with the situation. Out Bound Calls that are implemented at Telkomsel Branch Semarang are better used in the promotion of other products such as digital products. The results of the $\mathrm{OBC}$ which are considered to be effective should not make Telkomsel Branch Semarang feel that they have had enough, but must be further improved.

\section{References}

Bendremer, Ellen. 2003. Top Telemarketing Techniques. New Jersey: The Career Press.

Dianuhsani, D. (2019). Penerapan Bauran Promosi Produk Indihome Pada Pt Telkom Witel Karawang. Tugas Akhir Manajemen Pemasaran Undip. 
Fadhilah, F. (2018). Penerapan Sistem Penilaian Kinerja Pada Pt. Bank Woori Saudara 1906, Tbk Kantor Cabang Cirebon Jawa Barat. Retrieved From Eprints Undip: Http://Eprints.Undip.Ac.Id/61381/2/Bab_1.Pdf

Geetika, et. al. 2012. A Study of Indian Consumers' Perception on Telemarketing. International Journal of eEducation, e-Business, e-Management and e-Learning, Vol. 2, No. 2, April 2012

Hurst. C.G. 2008. Sustainable telemarketing? A new theory of consumer behavior. Direct Marketing: An International Journal Vol. 2 No. 2, pp. 111-124

Joshua Albert, A. F. (2018). Pengaruh Telemarketing Terhadap Keputusan Pembelian. Jurnal Administrasi Bisnis $U b, 22-24$.

Kotler. Philip. 2002. Manajemen Pemasaran Edisi Milenium, Jilid 3. Prenhallindo : Jakarta.

Kotler, Philip dan Armstrong, Gary. 2012. Principles of Marketing. New Jersey: Prentice Hall. Kotler, Philip, Kevin Lane Keller. (2012). Marketing Management, 14th Edition United States of America : Pearson

Nancarrow, C and Sally, P. Rapport in telemarketing- mirror, mirror on the call. Marketing Intelligence \& Planning, vol. 16, no. 1, pp. 12-21, 1998

Nurdin Usman, 2002, Konteks Implementasi Berbasis Kurikulum, Bandung, CV Sinar Baru

Shimp. Terence.2000. Periklanan Promosi: Aspek Tambahan Komunikasi Pemasaran Terpadu. Erlangga : Jakarta.

www.telkomsel.com

Yen, Y. W., Laksono, A. D., \& Yang, C. Y. (2019). Investigation of the interfacial reactions between Sn-3.0 wt\% Ag-0.5 wt\% Cu solder and CuTi alloy (C1990HP). Microelectronics Reliability, 96, 29-36. 